\title{
Ghana Youth Employment Program Inventory
}

\author{
August 2016
}

\section{Francis Babongte Avura and Ato Ulzen-Appiah}

The study was prepared for the World Bank with the support of the Programme for Sustainable Economic Development (PSED) in Ghana, implemented by the Deutsche Gesellschaft für Internationale Zusammenarbeit (GIZ GmbH) on behalf of the German Federal Ministry for Economic Cooperation and Development (BMZ). The authors wish to thank the various program staff who contributed to this work by reporting on the details of their programs. The comments and guidance of Christabel Dadzie and Kathleen Beegle are much appreciated. 


\section{CONTENTS}

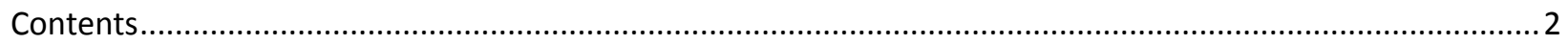

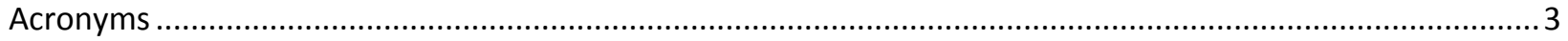

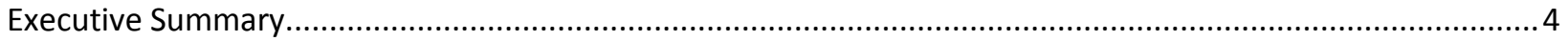

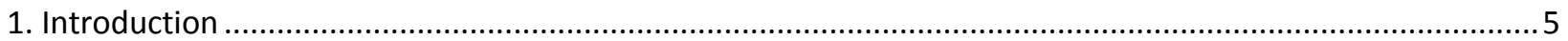

2. Key Components of Youth Employment Programs .......................................................................

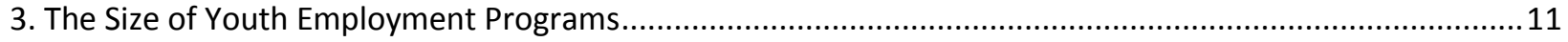

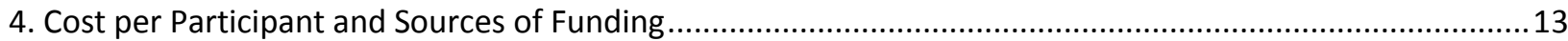

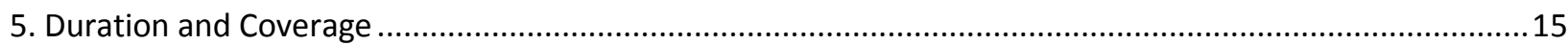

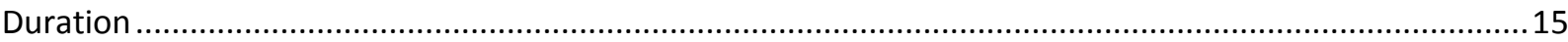

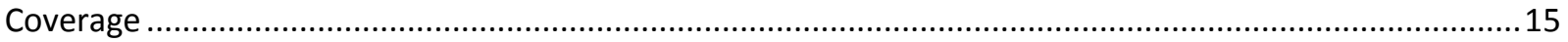

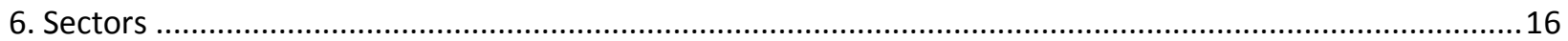

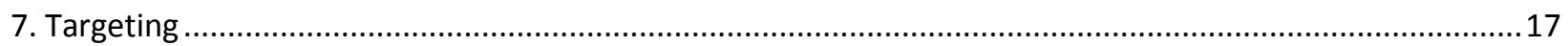

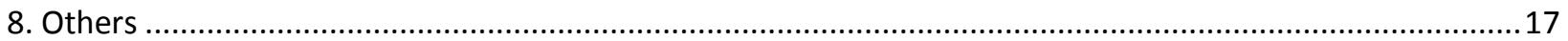

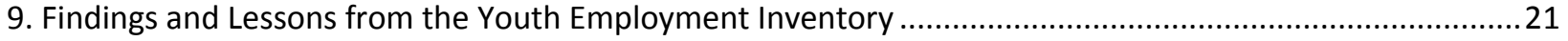

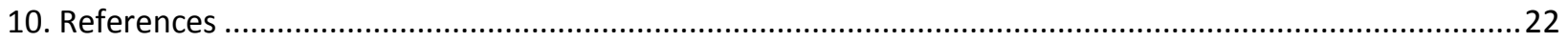

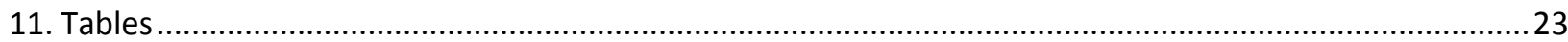

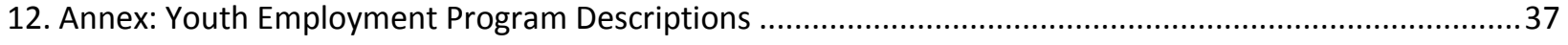

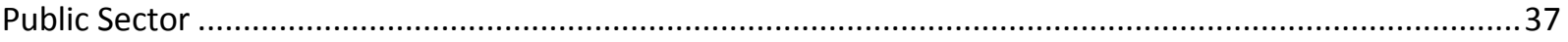

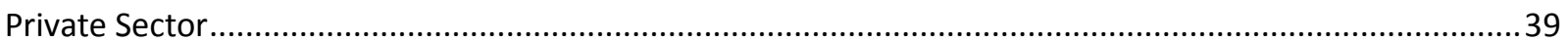




\section{ACRONYMS}

AEA African Entrepreneurship Academy

AITI- Advanced Information Technology Institute-Kofi Annan Center of Excellence in Information

KACE and Communication Technology

CAMFED Campaign for Female Education

COTVET Council for Technical and Vocational Education and Training

CSO civil society organization

DBC Diploma in Business Computing

ENGINE Enhancing Growth in New Enterprise (TecnoServe)

GEBSS Graduate Entrepreneurial Business Support Scheme

GIZ Deutsche Gesellschaft für Internationale Zusammenarbeit

GSDI Ghana Skills Development Initiative

ICCES Integrated Community Centers for Employable Skills

ICT information and communication technology

LEFY Livelihood Enhancement for Youth Program

LESDEP Local Enterprise Skills Development Program

M\&E monitoring and evaluation

MDAs ministries, departments, agencies

MDPI Management Development and Productivity Institute

MELR Ministry of Employment and Labor Relations

MOFA Ministry of Food and Agriculture

NAP National Apprenticeship Program

NGO nongovernmental organization

NVTI National Vocational Training Institute

OICG Opportunity Industrialization Centers Ghana

PII Phinklife Institute Initiative

SDC Skills Development Center (AEA)

YEA Youth Employment Agency

YES Youth Enterprise Support

YIEDIE Youth Inclusive Entrepreneurial Development Initiative for Employment

YLSTI Youth Leadership and Skills Training Institute 


\section{EXECUTIVE SUMMARY}

This Youth Employment Inventory has been compiled to improve the evidence base for making decisions about how to address the problem of youth unemployment or youth who are not in education and not participating in the labor market in Ghana. ${ }^{1}$ Policy makers who are considering measures to help young people make the transition into the labor market and obtain decent work are hampered by a lack of information on the various options, the effectiveness of the options in different situations, and options that have been tried and failed among different youth profiles. To guide public policy and inform private efforts, more evidence is needed about the effectiveness of different initiatives and approaches in promoting youth employment and fostering a smooth transition from education and training to work. This study takes a modest step in this direction by mapping youth employment initiatives in Ghana.

The government of Ghana has undertaken many initiatives to address the youth unemployment challenges. At the same time, many private sector organizations - some for private entities and others that are nonprofit efforts - have undertaken training programs to contribute to and improve the labor force in Ghana. The key focus of youth employment initiatives in Ghana is skills development and training, entrepreneurial training, apprenticeship, employment services, and direct employment. A total of 40 youth employment programs have been analyzed for this report. Of these, 18 are in the public sector and are implemented by government ministries, departments, and agencies (MDAs). The other 22 interventions are implemented by the private sector, which includes corporate entities, nongovernmental organizations (NGOs), and civil society organizations (CSOs). The existing programs are highly concentrated around skills development, training, and entrepreneurship training. Apprenticeship programs are more common in public sector programs, where over a third of programs offer apprenticeships.

The largest program by far is the one run by the Youth Employment Agency (YEA), which directly employs youth, employing 100,000 young people, 10 percent of the 1 million applicants. The private sector programs tend to be on a smaller scale relative to the public sector programs and are also more expensive. The cost per participant for wholly government-funded programs is low, at $\mathrm{GHC} 100-\mathbb{C} 150$, compared with private sector programs, for which the average cost per participant is GHC2,320. This partly reflects the scope of these respective programs as well as the targeted group of youth.

\footnotetext{
${ }^{1}$ Youth is not strictly defined in terms of age ranges. Programs self-identified as targeting youth or young people.
} 


\section{INTRODUCTION}

Africa is the youngest continent. Children and youth ages below 30 years constitute 70 percent of the continent's entire population (UNECA 2009). These young and energetic people of Africa have the potential, ability, creativity, enthusiasm, and energy to achieve Africa's renaissance. Investments in their education and improving their transition to employment are critical for the continent and Africa's global repositioning agenda. The 17th African Union Summit held in Malabo, Equatorial Guinea from June 28 to July 1, 2011, adopted a declaration that African Union member states would advance the youth agenda and adopt policies and mechanisms for the creation of safe, decent, and competitive employment opportunities by accelerating the implementation of the African Youth Decade Plan of Action (2009-18).

Ghana faces a significant unemployment problem, and youth are being affected the most. In Ghana, young people ages 15-35 represent about 34 percent of the population. Ashanti Region has the largest share of youth population (6.8 percent), followed by Greater Accra (6.2 percent), while the Upper West and Upper East regions have much lower shares, at 1.0 percent and 1.4 percent, respectively, reflecting their smaller overall populations. Youth often face unique challenges transitioning into the labor market. This is reflected in a range of labor indicators. Youth ages 15-24 are much less likely to be working than adults ages 25-65. Slightly more than half of young people are working (52 percent) compared with the majority of other adults ( 89 percent). This partly reflects the fact that young people are still in school, but, at the same time, a larger share of young people are neither in education nor working, compared with other adults. Youth frequently work in temporary low-wage, low-productivity jobs. This is reflected in the age gap in job satisfaction. Among those working, 23 percent of youth ages 15-24 report they are dissatisfied with their jobs, compared with 12 percent among the 25-34 agegroup and 9 percent among the 35-65 age-group. Younger workers are also more eager to change their jobs. Among people working, 47 percent in the 15-24 age-group, 39 percent in the 25-34 age-group, and 30 percent in the 35-65 age-group report they would like to change jobs (GSS 2014).

The reasons for these employment challenges among young people are varied. They range from deficits in basic education and job-relevant skills to lack of job search experience to facilitate job acquisition through working experience and difficulties in obtaining information about career options. Young job-seekers are more likely to lack the appropriate soft and hard skills, and this makes it difficult for them to secure employment. There is a skills mismatch. In addition to low skill levels, youth face higher barriers to employment stemming from their lack of access to finance, land, social networks, and other factors relative to adults.

The government of Ghana has undertaken many initiatives to address the challenges in youth unemployment. The National Youth Policy, "Towards an Empowered Youth, Impacting Positively on National Development," was launched in 2010. It is intended to provide guidelines for all stakeholders involved in the implementation of policies, programs, and projects for the development of youth. This was followed by the National Youth Policy 
Implementation Plan 2014-17. In 2015, the Ministry of Employment and Labor Relations (MELR) launched the National Employment Policy to address the employment situation and deal with deficits in decent jobs. It especially targeted vulnerable groups, youth, women, and the disabled. The goal of the policy is to create decent, gainful employment opportunities so the growing labor force can improve their living conditions and contribute to economic growth and national development within the framework of equity, fairness, security, and dignity. Policy efforts to expand employment outcomes among young people cut across the MDAs, including the Council for Technical and Vocational Education and Training (COTVET), which was established by Act of Parliament 718 in 2006 to coordinate and oversee all aspects of technical and vocational training in the formal and informal sectors. In 2012, Parliament passed a Legislative Instrument (LI 2195) to give legal backing to COTVET for the registration and accreditation of training providers in the public and private sectors. The National Apprenticeship Program (NAP) is implemented by COTVET as well as the Ghana Skills Development Initiative (GSDI), in collaboration with the Deutsche Gesellschaft für Internationale Zusammenarbeit (GIZ).

A variety of government programs are focused on youth employment. The government launched the National Youth Employment Program in 2006 to tackle the challenges of youth unemployment, underemployment, and food insecurity in the country by providing skills and job opportunities among youth. In 2012, the National Youth Employment Program was restructured into the Ghana Youth Employment and Entrepreneurial Development Agency, which was then restructured into the Youth Employment Agency (YEA) under Act 887 in 2015 to empower young people to contribute meaningfully to the sustainable socioeconomic development of Ghana. The YEA is but 1 of 17 public sector initiatives related to youth employment, albeit the largest in terms of youth coverage.

Another well-known program in Ghana related to youth employment is the National Service Scheme, whereby students who have completed all course work at the tertiary level are required to work in a job assigned to them through the scheme. There is frequent discussion about the mismatch between training and scheme placements and the implications for converting the experience gained during the service period into job placements. Twothirds of the participants complained about a mismatch between their field of study and their job placements (Sikah 2000). This program is not considered in this inventory.

Interest in promoting the employability of young people is not limited to public sector efforts. Many private sector organizations, some for profit and other nonprofit efforts, have undertaken training programs to contribute to and improve the labor force in Ghana. The oldest private sector program is the Fashion Training Program run by the Joyce Ababio College of Creative Design, started in 1995. Many private sector programs likewise tend to focus on training youth in the skills and sectors needed in particular industries. Private programs also pay special attention to addressing the lack of soft skills among many young graduates and out-of-school youth. 
While various interventions are being undertaken to address youth employment, systematic information on the scope of these programs is lacking. Moreover, little is known about what is most effective in promoting youth employment in Ghana. To guide public policy and inform private efforts, more evidence is needed about the effectiveness of various initiatives and approaches in fostering youth employment and smooth transitions from education and training to work. This study takes a modest step in this direction by mapping youth employment initiatives in Ghana.

The objective of this inventory is to provide inputs and background materials on youth employment initiatives in Ghana. The inventory of youth employment programs will be supplied to the MELR, as well as other coordinating ministries, development partners, and stakeholders, to aid in decision making on the development and implementation of youth employment programs in Ghana and to strengthen existing programs.

This inventory has been developed by listing existing youth employment programs and institutions operating in the public sector (MDAs), in the private sector (NGOs, private entities, and CSOs), and among development partners. The list has been updated based on the contact information of focal persons and key respondents. The list of public programs is considered exhaustive, whereas the list of private programs is likely not exhaustive.

A self-administered survey questionnaire on basic and core program details was distributed among key respondents in program management during multiple visits and meetings. In the case of some programs, the paper or digital questionnaires were accurately and completely filled out by key program respondents, while, in other programs, the information was verbally collected during meetings and face-to-face interviews. The data collection phase started in January 2016. It was originally envisaged to finish the data collection by the end of February 2016; however, it proved surprisingly difficult to obtain basic program information, especially from public sector institutions. The period of data collection was therefore extended another two months, to April. 


\section{KEY COMPONENTS OF YOUTH EMPLOYMENT PROGRAMS}

For the purposes of this inventory, youth employment interventions refer to programs designed to improve the employability and employment prospects of young people ages 15-35 years who are outside the formal education system. There are numerous types of youth employment programs, including wage subsidies or grants, public works programs, self-employment programs, cash grants, and entrepreneurial promotion programs (Cho and Honorati 2014). To classify youth employment programs in Ghana, six categories were defined, as follows:

1. Skills development and training entails the provision of vocational and technical skills through formal training institutes and schools (class-based training) or within an organized and structured workplace environment such as a registered firm or an informal business (on-the-job training). This is explicitly designated as learning (in terms of objectives, time, or resources) and typically leads to validation or learning assessments and certification. This includes short- and long-course programs up to, say, two years, such as through the National Vocational Training Institute and the Youth Leadership Training Institute.

2. Programs to foster entrepreneurship are focused on building business knowledge, practices, and skills, explicitly in preparation for starting a business or improving an existing enterprise. These are often programs that focus on both hard and soft skills; they center on the attitudes, knowledge, and other skills associated with the practice of entrepreneurship. They may include start-up credit financing (Youth Enterprise Support [YES] and the Enablis Business LaunchPad), incubation (the Meltwater Incubator Program), business advisory services (YES and the ServLed Accelerator Program), and mentorship (Enhancing Growth in New Enterprise [ENGINE]).

3. Youth employment services include the provision of labor market information (on, for example, economic sectors, enterprises that are creating jobs, geographical areas where labor demand is higher, education streams that teach the skills required in high-demand occupations), general employment counseling, including guidance on how to approach employers, the specific identification of appropriate job vacancies, and how to write a curriculum vitae and manage job interviews.

4. Direct employment is the provision of employment, usually in the public sector.

5. Apprenticeship is a system by which an employer hires a young person as an apprentice and trains the person systematically in a trade, while the apprentice works in the employer's service. Traditional apprenticeship opportunities in Ghana are most often available in the informal sector, are not associated with a written contract, and are based on an unwritten agreement between the apprentice and the microenterprise owner. They last an average of three years, and the apprentice receives a minimum monthly subsistence allowance. In terms of the programs inventoried here, the apprenticeship component is more highly structured. The apprentice is often paired with a prescreened master craftsman, who is paid by the apprenticeship program to take on the apprentice. The fees paid by the apprentice, the duration of the apprenticeship, and the mode of assessment of the apprentice differ across programs. 
6. Others is a residual category to capture any remaining components of youth employment programs in Ghana not already listed. Specific examples are discussed below. Some of the modules being implemented by the YEA include programs whereby university or tertiary students are placed mostly in government MDAs during vacation to perform specific jobs, for instance, revenue mobilization. There are also YEA internship program modules whereby students in senior high school, tertiary institutions, and technical and vocational institutes are placed in public or private organizations as part of their training to acquire knowledge and first-job experience to enhance employability.

One program may be mapped to one or more types based on the program components or activities. Tables $1 \mathrm{~A}$ and $1 \mathrm{~B}$ show the range of activities covered by the 40 youth employment programs of public and private implementing agencies. Of these 40,18 are in the public sector and are being implemented by government MDAs. The other 22 interventions are being implemented by the private sector, which includes corporate organizations, NGOs, and CSOs. (The public and private nature of the programs in this report refers to the nature of the implementing agency, not the financing.)

Skills development and training dominates the types of programs implemented, with a total of 30 interventions, 14 in the public sector, and 16 in the private sector. Many skill training programs in the public sector focus on vocational skills and are run similarly to senior high school education. Of the 7 public sector interventions implemented by the MELR, 5 are skills development and training programs. The second most common type of youth employment program is entrepreneurial training ( 24 of 40 programs), which is especially prevalent in the nonpublic programs, where 17 of 22 private sector programs tackle entrepreneurial training.

Apprenticeship programs are more common in public sector programs, where over a third of programs offer apprenticeships. Apprenticeships represent an opportunity for youth to become prepared for self-employmentpotentially, also wage employment if the person is hired by a master craftsman — through exposure to the world of work and through on-the-job learning of job-relevant skills in the specific trade in which they are involved.

Traditional apprenticeship is widespread in the informal sector, where apprentices are the ones learning a trade or skill from qualified individuals (master craftspersons) for a period of time that has been fixed in advance. The GSDI, which is implemented by COTVET and funded by GIZ, seeks to improve on traditional apprenticeship through innovative approaches to the introduction of competency-based training standards and a cooperative training model combining workplace and school-based training.

While curriculum content and design need to be specific to the sector of focus and the type of youth in the program, there is nonetheless likely to be considerable overlap among the different types of youth employment programs. The sense from the data collection effort and discussions with focal persons in programs is that there is little coordination or communication across programs, not even in programs in the same MDA. For example, 
some modules of entrepreneurship training for microenterprises, notably key concepts of general business training, are not sector- or trade-specific but are common across different training courses. To this end, it may be efficient to have one core set of materials that pertain to this content and that are available and used systematically at least by the government programs that carry out entrepreneurship training. 


\section{THE SIZE OF YOUTH EMPLOYMENT PROGRAMS}

The size of programs in terms of youth participation is presented in tables $2 \mathrm{~A}$ and $2 \mathrm{~B}$. Among the public initiatives, the largest program by far is the YEA, which directly employs 100,000 young people (out of 1 million applicants). The Youth in Agriculture Program under the Ministry of Food and Agriculture (MOFA) is the second largest program, with 50,000 youth in training each year. Applications are double the number of those accepted. In a close third place is the Youth in Cocoa Program, to which 50,000 young people have applied, and 42,000 young people have been trained. Both programs support youth by supplying farm inputs and extension services. The fourth largest program is the Rural Enterprise Program under the Ministry of Trade and Industry. It covers 26,980 youth per year and has the lowest acceptance rate, about a third of applicants. The Rural Enterprise Program primarily targets the entrepreneurial poor. Generally, there is no age restriction. However, for special youth support interventions, such as the Youth in Agri-business Program that is being implemented in collaboration with MOFA, the age range is $18-35$ years. It is estimated that 38 percent of the participants are youth ages 18-35 years. The Competency Training for Fresh and Unemployed Graduates Program implemented by the Management Development and Productivity Institute (MDPI) recorded the lowest number of young people, at 6. The low intake reflects the fact that the primary target of MDPI is not youth, the initiative does not have much funding, and the fees are expensive. In general, programs receive many more applicants than they enroll. Oversubscription is high especially among programs that do not require youth to pay a fee. However, further investigation is needed to understand if this occurs because of a lack of qualifications among applicants, the lack of program capacity to accept more applicants, or other reasons.

Private sector programs tend to have smaller geographical coverage relative to the public sector programs, which are national in character. The application processes that beneficiaries must undergo to join these programs are intensely competitive. Beneficiaries must also compete for the limited available grants or credits to start their businesses. Many of these programs spend significant resources on trainees. The biggest private sector program is the Local Enterprise Skills Development Program (LESDEP), which has a much larger number of beneficiaries, 35,000, in part because of support and funding supplied by the government.

The private sector programs (22) are not designed to solicit applications from a large number of people and so tend to have much smaller numbers of applicants $(140,000)$. The intake capacity of these programs is also small. On average, the take-up rate is 58 percent, compared with 21 percent among the public sector programs. Combined, the 16 programs that focus on skills development admit more participants than the 17 programs with a focus on entrepreneur training. Many competitive entrepreneurial programs are able to take fewer than 50 percent of the applicants to ensure high-quality in their services within their restricted budgets. For example, the Meltwater Entrepreneurial School of Technology accepts only 3 percent of the applicants. Quality certification 
programs with high fees have few participants because they focus on providing high-quality training, not the quantity of applicants.

Overall, the number of youth being covered by the programs inventoried here — approximately 320,000 — is a small fraction (less than 4 percent) of the approximately 9 million youth ages $15-35$, some of whom are in school or successfully employed. From this perspective, it is unlikely that youth employment programs could be scaled up to affect a significant shift in the statistics on youth employment. Nonetheless, for the participants, these programs offer an opportunity for young people to change their employment trajectory meaningfully. 


\section{COST PER PARTICIPANT AND SOURCES OF FUNDING}

Reasonably robust unit cost data on the various interventions have been difficult to obtain. Budget data of the sponsoring ministries or organizations are often not appropriately disaggregated, and precise information on the target beneficiaries who have been reached may be imprecise. Unit cost data on private initiatives have usually not been available for this inventory. Some government programs (MDPI, YES, Youth in Cocoa) and private programs (the Campaign for Female Education [CAMFED], ServLed) declined to provide annual budget information.

Tables 3A and 3B show that cost differences were considerable even among programs of similar nature and duration. The cost per participant of wholly government-funded programs is as low as GHC100 and as high as GHC60,000, compared with the private sector, where the cost per participant ranges from GHC100 to GHC500,000. Private programs are more expensive than public programs. The total annual budget for the private sector programs listed in table 3B is GHC103 million, and the average cost per participant is GHC35,090, compared with the public sector, where the average annual budget among the programs shown in table $3 \mathrm{~A}$ is GHC835,103,398, while the annual average cost per participant is GHC3,475. The reason for a high average cost per participant in the private sector is (1) the higher recurrent and overhead costs for similar program activities; private sector programs rely on legal and financial consultants and more expensive, more highly skilled training providers, and (2) the more expensive program activities such as the provision of start-up grants for beneficiaries, but also the provision of complementary training services, such as business advisory services and coaches, mentorships, and incubation. Analyses have found that the private sector hires legal and business advisory people to make the training more practical, which is not the case in the public sector. This also contributes to the higher average cost per participant. The difference in program costs likewise reflects variations in program priorities, budget allocations, and funding capacity, as well as the ability of youth to pay the fees and the fact that these programs often run longer.

The majority of the public programs listed in table $3 \mathrm{~A}$ are funded by the government; few are supported by development partners or international organizations. Only one program, the Graduate Entrepreneurial Business Support Scheme (GEBSS), is a public-private partnership, in this case between the Jospong group of companies, the State Insurance Company, and other private companies and the government through the MELR. Most of the private sector programs listed in table $3 \mathrm{~B}$ are funded by corporate organizations as part of their efforts at corporate social responsibility or by NGOs, international organizations and development partners.

Some of the private programs (such as Enablis LaunchPad) and some public programs (GEBSS, NAP, and Youth in Agriculture) have been put on hold because of a lack of adequate funding and support. 
The fees charged and collected from beneficiaries cover the costs involved in running many training programs in Ghana. In table 3A, 9 of the 18 public sector programs do not charge any fees to their beneficiaries; government funding covers the costs. The fees are not always the same for similar interventions across programs. In the Rural Enterprise Program, participants are charged 20 percent to 100 percent of the costs depending on the level and type of support and the status of the business of the clients. The fees charged often correspond to the economic environment within which the program is operated. Beneficiaries are charged GHC290 for the Livelihood Enhancement for Youth Program (LEFY) of the Opportunity Industrialization Centers Ghana (OICG), but many face difficulties paying the fee. For the technical and vocational education and training program of the Integrated Community Centers for Employable Skills (ICCES), the fees of a few trainees are subsidized by some NGOs because the parents cannot afford the payments. The Diploma in Business Computing (DBC) Program of the Advanced Information Technology Institute-Kofi Annan Centre of Excellence in Information and Communication Technology (AITI-KACE) is the most expensive (GHC4,200), followed by the MDPI's Competency Training for Fresh and Unemployed Graduates, which costs GHC4,000, but is subsidized in some cases by various institutions.

In the private sector, 13 of the 22 programs are free (table $3 b$ ). Of the free programs, four are focused on entrepreneurial training: the Meltwater Foundation's Entrepreneur-in-Training Program, ENGINE by TechnoServe, the ServLed Accelerator Program, and the Enablis LaunchPad. Others, such as Impact Hub Accra's Venture Support, charges membership fees to beneficiaries. The most expensive program is the Cake Craft Training Program of Stesi Cakes (GHC1,800). 


\section{DURATION AND COVERAGE}

Most entrepreneurial programs focus on year-round support for the entrepreneurs in training. In skills development programs, the youth are tested regularly to ensure proper training, and they receive certification after completion. Program duration varies based on the type of industries and sectors targeted.

\section{Duration}

More than half the public sector programs last three or more years (table 4A). These programs offer certification to graduates. YES runs for two business cycles (at least two years); the duration depends on the entrepreneurs. The program of the Youth Leadership and Skills Training Institute (YLSTI) is the oldest youth employment training program in Ghana, started in 1974. ICCES started in 1986 and runs programs that last six months, two years, and four years. Also, within the public sector, MDPI programs run for 10 days and include intensive training on competency and productivity.

In the private sector (table 4B), the incubator programs run by Meltwater and by the Reach for Change Foundation last an average of three to five years, but entrepreneurs exit early if they are able to attain adequate capacity.

CAMFED training lasts a week. However, follow-up monitoring and coaching lasts another 12 weeks to ensure the training has taken hold. Many of the skills programs in the private sector involve intensive training over periods of one week to six months. Graduates continue to benefit from these programs through after-care options (periodic phone calls and workshops).

\section{Coverage}

Most public sector programs are nationwide. The Youth Inclusive Entrepreneurial Development Initiative for Employment (YIEDIE), a private sector program, is run in Accra and Takoradi, operates on the weekends (Saturday and Sunday), and targets workers who want to build their soft skills to become more employable in the construction industry. In Takoradi, the program works with the local government assembly to support the program and attract applicants.

There are a few regional programs. CAMFED Ghana runs programs in the three northern regions and the Central Region, which is generally regarded as one of the poorest regions. In contrast, most of the private sector programs are active in Accra. The entrepreneur-focused programs, while based in Accra, include participants all over the country. The Teacher Professional Development Program is run in a number of districts, where its activities are driven by the financial supporters. 


\section{SECTORS}

Employment in Africa is predominantly in the agriculture sector and the informal economy. This is true of Ghana as well. In Ghana, 43 percent of the employed youth population are active in the service sector, followed by 41 percent in agriculture, forestry, and fishing, while 19 percent are employed in wholesale and retail trade and automobile and motorcycle repair. Electricity, gas, stream power, and air conditioning account for 0.4 percent of employed youth, and water supply, sewerage, and waste management engage 0.2 percent. Because the number of new vacancies in the formal sector is not catching up with the number of new young people looking for jobs, young people find the informal sector and agriculture as the only options.

Over 90 percent of the programs provide training for work in the informal sector, but only YEA provides some form of wage employment in the formal sector in collaboration with government MDAs (tables 5A and 5B). Only a few programs (the Fisheries Commission, YEA, Youth in Agriculture, and Youth in Cocoa) are engaged in the agricultural sector. The dominant sectors involved in program training activities shown in table 5A are construction, consumer electronics, hair and beauty, automobile repairs, catering, and dressmaking and tailoring.

The majority of the private sector programs focus on providing skills in information and communication technology (ICT), entrepreneurship, hospitality, fashion and design, beauty care, and general business. Impact Hub Accra, ServLed, and Meltwater focus on entrepreneurship; most of their beneficiaries are in the ICT sector or leverage ICT for their enterprises. The Youth and Farm Market Program trains farmer apprentices who will eventually own farms, showing the willingness of the private sector to dabble in agriculture, the dominant sector of the economy. 


\section{TARGETING}

The reviewed programs target different segments of the youth population by age and by background, especially in terms of educational attainment.

The minimum age requirement of 80 percent of the youth employment training programs, in both the public and private sectors, is 18 , which, in principle, is the age at which a student would finish senior high school.

Public programs are generally targeted at youth who have completed secondary education, while private programs require higher skills and a tertiary education diploma or certificate. Ten private sector programs exclusively target youth who have completed tertiary education, while only three public programs do so. Programs focused on entrepreneurial activities in the private sector generally target youth who have finished tertiary education and current professionals looking to run their enterprises full time. Many skills development programs, such as YIEDIE and the African Entrepreneurship Academy (AEA) Skills Development Center (SDC), target students who have completed secondary education, but who have not continued on in tertiary education. Public sector programs are nationwide and target rural youth and youth in low-income households who have, on average, lower educational attainment.

The majority of the private sector programs are concentrated in urban centers, especially Accra, and are therefore not available to rural youth. Almost all private sector programs (18 of 22) exclusively target 18- to 35-year-old youth, while only half the public sector programs target youth exclusively. Eight of the private sector programs accept youth who are in or have completed high school education. CAMFED Ghana and Savana Signatures have programs that target junior high school students, equipping them for employment in case they do not continue their education. Of the private sector programs, 12 accept youth who are in or have completed senior high school. Student-focused programs (run by Enactus and TANOE) work with students throughout the four years of tertiary education to train entrepreneurs.

\section{OTHERS}

This section reviews other services, including components, issues, and problems addressed (tables 7A and 7B).

Exit strategies: An exit strategy is the approach a program adopts to aid the transition of a program participant out of the program. This may include complementary services after the participant has completed the program. More than half the youth employment programs analyzed do not have clear, coordinated exit strategies for beneficiaries. For example, only three public sector programs have some form of exit strategy (YEA, Youth in Agriculture, and Youth in Cocoa). In collaboration with government MDAs, YEA aims to create viable and sustainable employment opportunities for youth in the formal sector, including in security services (community policing, prison services, fire and immigration services) and as community teaching assistants or health workers. 
The beneficiaries are supposed to work in the various government agencies for two years, after which they are supposed to be employed as permanent staff. However, this exit strategy is not effectively implemented by the various government agencies because of financial constraints and a ban on employment in the public sector. As a result, these beneficiaries do not exit the program as planned. Meanwhile, YEA financial support involves offering interest-free loans to qualified start-up and existing businesses owned by youth. While the Youth in Agriculture and Youth in Cocoa programs provide farm inputs, such as fertilizer and seeds, as well as extension services to beneficiaries. However, private sector and donor-funded programs provide start-up grants or interestfree loans, mentorship, incubation, and business advisory services to youth. Upon completion of the programs, private sector programs more frequently offer cash and credit support, while public sector programs offer more often focus on in-kind support.

Tracer study: Tracer studies are common research tools to track the employment and earning trajectories of program participants after program completion, especially among educational and training programs. The institutions analyzed here use the results of tracer studies, as well as other monitoring and evaluation (M\&E) tools, such as beneficiary assessments, process evaluations, employer surveys in case of internships and apprenticeships, to improve the design and implementation of programs and to enhance the learning experiences of future learners. However, in Ghana, critical knowledge gaps exist, especially on the effectiveness and impact of various initiatives. A particular problem is the lack of impact evaluations on the large-scale government-run youth employment programs given that substantial public funding has been allocated to these programs. For example, since 2006, when it was launched, no systematic and comprehensive tracer studies have been conducted on YEA. Only three interventions, ICCES, the National Vocational Training Institute (NVTI), and OICG, have made tracer studies available that have been funded by development partners and international organizations. For instance, NVTI followed a group of 2007-10 graduates and found that, by 2012, 53 percent were selfemployed within between six months and one year after completion of their training; 31 percent were in wage employment; 12 percent were continuing their training; and 4 percent were not working. A study of the LEFY program of OICG in 2013 assessed the quality of graduates and their competitiveness in the labor market. It concluded that 95 percent of LEFY graduates were employed full time and applying the skills they had acquired. Four of the 23 private sector programs carried out tracer studies: the AEA SDC program, the certificate program of the Joyce Ababio College of Creative Design, LESDEP, and YIEDIE. The study of the AEA SDC program found that 70 percent of the graduates had started their own businesses.

Challenges: The survey collected insights on the major challenges that program directors felt their efforts face. All programs seeking to improve employment outcomes face common economy-wide challenges (poor roads, energy shortages, telephone outages, and a challenging business environment). Public sector programs encounter a range of challenges driven by an ever-expanding mandate, but insufficient funding and, as a result, obsolete tools and equipment, difficult infrastructure, inadequate instructional staff, lack of vehicles for monitoring, poor 
office accommodations, irregularly paid master craftpersons or trainers, inability to provide graduates with startup kits, and incapacity to scale up scale interventions in all regions). For example, the challenges of the agriculture sector affect the ability of the Youth in Agriculture Program to become a viable source of employment for youth because of poor access to land, a shortage of seeds and fingerlings, and a lack of access to finance and savings.

The challenges among private sector programs include not only inadequate funding to scale up interventions, but also barriers to sustainability. In the case of Impact Hub Accra, translating business models to the local environment for companies has not been easy. Problems also arise because of the poor quality and high cost of data and delays in establishing an alumni network to share lessons on best practice given the large numbers of former participants and the lack of an appropriate communication platform. According to the ENGINE Program implemented by TechnoServe, the major challenge is beneficiaries who turn the competition for program participation into opportunities to access funding.

Successes: Many of the private sector programs measure success through the successes of their graduates. They emphasize the importance of encouraging alumni to share knowledge and experiences with current beneficiaries. Some programs, such as Enablis, use surveys among beneficiaries to measure their success. ENGINE of TechnoServe had received an A and an A+ rating (very good and very strong) from its donor, the U.K. Department for International Development, as of the first quarter of 2016. There has been 174 percent revenue growth across the enterprises in the ENGINE accelerator program, and 283 new jobs were created in 2015. The Reach for Change Program had a positive effect on the lives of over 400,000 children in 2015 through the interventions of social entrepreneurs. The Meltwater Incubator Program has had two highly successful graduate exits through the creation of new enterprises: ClaimSync (by Genkey), and Saya (by Kirusa). Meqasa received funding from Frontier Digital Ventures to the tune of $\$ 800,000$; Kudobuzz + Dropifi were both at the internationally acclaimed 500 Startups accelerator. There have also been several international competition wins such as Seedstars by Asoriba, the Launch Business Conference by Nandimobile, Africa Entrepreneur Awards by Leti Arts, among others.

The public sector programs tend to measure success by the percentages of their beneficiaries who find employment, though the studies are limited. The Youth in Cocoa Program has been able to augment the number of farmers, thereby offsetting the loss of cocoa farmers through aging that is a major concern of the government in terms of potentially declining cocoa yields and the associated exports. The area of cocoa cultivation has been expanded. Of the graduate trainees of the Apprenticeship Testing and Assessment Program of GRATIS, 53 percent are now self-employed. The Rural Enterprise Program employed about 600 new staff, who eventually supported the creation of 27,000 small and medium enterprises that employ about 65,000 people. 
Future plans: The majority of the private sector programs plan to scale up. Many intend to strengthen their alumni networks and build better models of sustainability. Some (for example, the Phinklife Institute Initiative [PII]) intend to launch a youth bank model to raise funds for the program. The Youth and Farm Market Program will partner with organizations implementing a similar program to build momentum to help target groups succeed. The program is also expected to launch a web presence for all its interventions. The Venture Support Program of Impact Hub Accra plans to have four accelerator programs by the end of 2016: agriculture, health care, culture, and education. Impact Hub Accra is raising an initial \$1 million seed fund for these programs and will be expanding a building next door to accommodate more global start-ups.

The future plans the public sector Youth in Cocoa Program include expanding to cover all regions where cocoa is grown and provide necessary incentives to attract more youth. The Technical Apprentice and Skills Training Program plans to provide start-up kits for trainees, while seeking funding from donor agencies and development partners. The LEFY program implemented by OICG plans to seek partnerships with development partners to scale up to all regions in Ghana. YES has been supporting 1,000 young entrepreneurs a year since 2017 and obtained a policy directive to facilitate a steady flow of funding. The YLSTI has been expanding its infrastructural capacity by building more classrooms, dormitories, and workshops to admit more youth.

M\&E: M\&E is an indispensable learning and management tool for improving current and future program planning, implementation, and decision making. It forms the basis of evidence-based policy making in which the focus is on outcomes rather than inputs. A performance evaluation would gauge the input-output relationship and the immediate outcomes of a program at a point in time. It then assesses the design and implementation of the intervention against criteria of relevance, effectiveness, and efficiency. A performance monitoring system supports the evaluation by providing information on trainee completion rates, the share of participants who pass competency tests, and employment rates and earnings among graduates. An impact evaluation provides evidence on whether the changes in completion rates and the labor market performance of trainees were caused by the intervention alone. However, the identification of determinants of program effectiveness is hampered by a lack of systematic knowledge about results and impact. Most programs, including the large-scale government sponsored programs, have not been comprehensively evaluated.

One of the major challenges of this inventory is the lack of thorough evaluations and impact assessments of most of the initiatives. This has limited the study's ability to gauge the effectiveness of the programs. Of the 40 youth employment programs or institutions in the public sector and the private sector recorded in this inventory have not provided M\&E reports even though they were asked to provide them. While the majority of the programs have some monitoring system in place and have done some evaluation, they failed to present reports. 


\section{FINDINGS AND LESSONS FROM THE YOUTH EMPLOYMENT INVENTORY}

1. In Ghana, obtaining data or information from authoritative sources in the public and private sectors is extremely difficult.

2. There is substantial duplication in youth employment training programs. As a result, there have been major challenges in coordinating responses to youth employment issues in the country.

3. Private sector programs should collaborate and share lessons on best practice with public programs.

4. The majority of government programs do not conduct baseline surveys and impact studies or evaluations and do not possess comprehensive or even adequate M\&E systems.

5. Strengthening employment in the informal sector is crucial to addressing youth unemployment, which requires specific policies and interventions to increase the capacity of the informal sector and the agriculture sector to absorb young people.

6. The majority of the programs do not provide support or follow-up services for beneficiaries.

7. Most government programs are underfunded, and some have been put on hold because of financial constraints (GEBSS, NAP, Youth in Agriculture).

8. Most private sector programs are located in urban areas (mostly Accra) and are not accessible to rural youth.

9. Most private sector programs are well-funded, good-quality programs and provide competitive start-up grants and loans, mentorship, international exposure, and other businesses advisory services to beneficiaries.

10. Most private sector programs are competitive, especially in entrepreneurial programs that require tertiary educational attainment among participants.

11. Some private sector programs are run by companies that train youth to be employable in their industries. They are not well funded, and the costs are high for the trainees. 


\section{REFERENCES}

Cho, Y., and M. Honorati. 2014. "Entrepreneurship Programs in Developing Countries: A Meta-Regression Analysis." Labor Economics 28: 110-13.

GSS (Ghana Statistical Service). 2014. "Ghana Living Standard Survey Round 6 (GLSS6): Labour Force Report.” August, GSS, Accra, Ghana.

Sikah, V. P. K. 2000. "The Ghana National Service Scheme: Perceptions of Former Educational Personnel, Students, and Guardians." Unpublished PhD dissertation, Florida International University, Miami.

UNECA (United Nations Economic Commission for Africa). 2009. African Youth Report 2009: Expanding Opportunities for and with Young People in Africa. Report ECA/ACGS/HSD/AYR/ 2009. Addis Ababa, Ethiopia: UNECA. 


\section{TABLES}

Table 1A. Key components of youth employment programs, public sector

\begin{tabular}{|c|c|c|c|c|c|c|c|c|}
\hline Program & MDAs & $\begin{array}{c}\text { Skills } \\
\text { development \& } \\
\text { training }\end{array}$ & $\begin{array}{c}\text { Entrepreneurial } \\
\text { training }\end{array}$ & $\begin{array}{c}\text { Employment } \\
\text { services }\end{array}$ & Employment & Apprenticeship & Others & $\begin{array}{c}\text { Support to } \\
\text { beneficiaries }\end{array}$ \\
\hline YEA & MELR & $\checkmark$ & & $\checkmark$ & $\checkmark$ & $\checkmark$ & $\checkmark$ & $\begin{array}{c}\text { Lump sum after } \\
\text { two years }\end{array}$ \\
\hline NVTI & MELR & $\checkmark$ & $\checkmark$ & & & $\checkmark$ & & \\
\hline GEBSS & MELR & & $\checkmark$ & & & & & \\
\hline $\begin{array}{l}\text { Corporative } \\
\text { Council }\end{array}$ & MELR & $\checkmark$ & & & & & & \\
\hline ICCES & MELR & $\checkmark$ & & & & & & \\
\hline OICG & MELR & $\checkmark$ & $\checkmark$ & & & $\checkmark$ & & \\
\hline MDPI & MELR & & $\checkmark$ & & & & & \\
\hline $\begin{array}{l}\text { Youth in } \\
\text { Agric. }\end{array}$ & MOFA & $\checkmark$ & & & & & & $\begin{array}{c}\text { Farm inputs \& } \\
\text { extension } \\
\text { services }\end{array}$ \\
\hline $\begin{array}{l}\text { Youth in } \\
\text { Cocoa }\end{array}$ & MOFA & $\checkmark$ & & & & & & $\begin{array}{c}\text { Farm inputs \& } \\
\text { extension } \\
\text { services }\end{array}$ \\
\hline $\begin{array}{l}\text { GRATIS } \\
\text { Foundation }\end{array}$ & $\begin{array}{l}\text { Ministry of Trade } \\
\text { and Industry }\end{array}$ & $\checkmark$ & $\checkmark$ & & & $\checkmark$ & & \\
\hline $\begin{array}{l}\text { Rural } \\
\text { Enterprise } \\
\text { Program }\end{array}$ & $\begin{array}{l}\text { Ministry of Trade } \\
\text { and Industry }\end{array}$ & $\checkmark$ & & & & & & \\
\hline $\begin{array}{l}\text { COTVET- } \\
\text { NAP }\end{array}$ & $\begin{array}{l}\text { Ministry of } \\
\text { Education }\end{array}$ & $\checkmark$ & & & & $\checkmark$ & & \\
\hline $\begin{array}{l}\text { COTVET- } \\
\text { GSDI }\end{array}$ & $\begin{array}{l}\text { Ministry of } \\
\text { Education }\end{array}$ & $\checkmark$ & & & & $\checkmark$ & & \\
\hline YLSTI & $\begin{array}{l}\text { Ministry of Youth } \\
\text { and Sports }\end{array}$ & $\checkmark$ & & & & & & \\
\hline YES & Office of President & & $\checkmark$ & & & & & \\
\hline $\begin{array}{l}\text { Microfinance } \\
\text { and Small } \\
\text { Loans Center }\end{array}$ & Office of President & & & & & & $\checkmark$ & NA \\
\hline $\begin{array}{l}\text { Fisheries } \\
\text { Commission }\end{array}$ & $\begin{array}{l}\text { Ministry of } \\
\text { Fisheries and } \\
\text { Aquaculture } \\
\text { Development }\end{array}$ & $\checkmark$ & & & & & & \\
\hline $\begin{array}{l}\text { DBC, Mobile } \\
\text { Applications } \\
\text { Development }\end{array}$ & $\begin{array}{c}\text { Ministry of } \\
\text { Communications }\end{array}$ & $\sqrt{ }$ & $\checkmark$ & & & & & None \\
\hline Total & & 14 & 7 & 1 & $\mathbf{1}$ & 6 & 2 & \\
\hline
\end{tabular}


Table 1B. Key components of youth employment programs, private sector

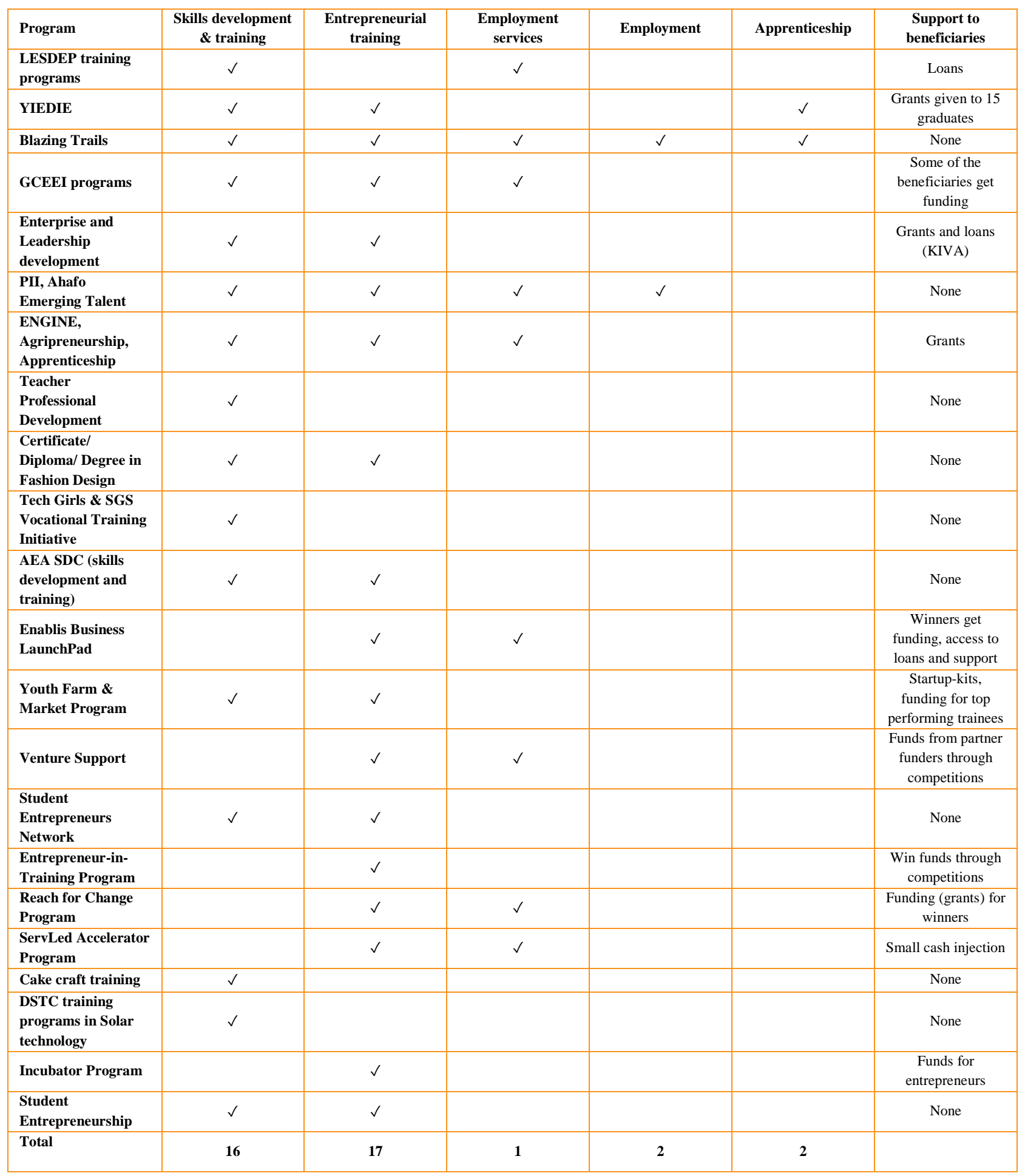


Table 2A. Size of youth employment programs, public sector

\begin{tabular}{|c|c|c|c|}
\hline Program & \# of youth apply per year & $\begin{array}{c}\text { \# of youth allow in a } \\
\text { program per year }\end{array}$ & Percentages \% \\
\hline YEA & $1,000,000$ & 100,000 & 10 \\
\hline NVTI & 5,000 & 4,000 & 80 \\
\hline GEBSS & 3,000 & 2,000 & 67 \\
\hline Corporative Council & 1,500 & 1,000 & 67 \\
\hline ICCES & 3,500 & 3,000 & 85 \\
\hline OICG & 1,200 & 350 & 29 \\
\hline MDPI & 15 & 6 & 40 \\
\hline Youth in Agric. & 100,000 & 50,000 & 50 \\
\hline Youth in Cocoa & 50,000 & 42,882 & 86 \\
\hline GRATIS Foundation & 5,000 & 2,194 & 44 \\
\hline Rural Enterprise Program & 80,000 & 26,980 & 34 \\
\hline COTVET-NAP & 10,000 & 5,000 & 50 \\
\hline COTVET-GSDI & 2,400 & 1,500 & 63 \\
\hline YLSTI & 3,000 & 1,500 & 50 \\
\hline YES & 300 & 107 & 36 \\
\hline Microfinance and Small Loans Center & NA & NA & NA \\
\hline Fisheries Commission & 300 & 100 & 33 \\
\hline DBC, Mobile Applications Development & 55 & 55 & 100 \\
\hline Total & $1,265,270$ & 270,674 & 19 \\
\hline
\end{tabular}


Table 2B. Size of youth employment programs, private sector

\begin{tabular}{|c|c|c|c|}
\hline Program & \# of youth apply per year & \# of youth allow in a program per year & Percentages \% \\
\hline LESDEP training programs & 129000 & 35000 & 27 \\
\hline YIEDIE & 1800 & 1600 & 89 \\
\hline Blazing Trails & 4000 & 1500 & 38 \\
\hline GCEEI programs & 1200 & 1000 & 83 \\
\hline Enterprise and Leadership development & 1010 & 610 & 60 \\
\hline PII, Ahafo Emerging Talent & 3000 & 335 & 11 \\
\hline ENGINE, Agripreneurship, Apprenticeship & 1500 & 215 & 14 \\
\hline Teacher Professional Development & 300 & 200 & 67 \\
\hline Certificate/ Diploma/ Degree in Fashion Design & 200 & 171 & 86 \\
\hline Tech Girls \& SGS Vocational Training Initiative & 140 & 140 & 100 \\
\hline AEA SDC (skills development and training) & 100 & 100 & 100 \\
\hline Enablis Business LaunchPad & 100 & 75 & 75 \\
\hline Youth Farm \& Market Program & 80 & 60 & 75 \\
\hline Venture Support & 54 & 54 & 100 \\
\hline Student Entrepreneurs Network & 500 & 50 & 10 \\
\hline Entrepreneur-in-Training Program & 1000 & 30 & 3 \\
\hline Reach for Change Program & 200 & 24 & 12 \\
\hline ServLed Accelerator Program & 30 & 20 & 67 \\
\hline Cake craft training & 20 & 20 & 100 \\
\hline DSTC training programs in Solar technology & 60 & 15 & 25 \\
\hline Incubator Program & 30 & 8 & 27 \\
\hline Student Entrepreneurship & N/A & N/A & N/A \\
\hline Total & 144.324 & 41,227 & $29 \%$ \\
\hline
\end{tabular}


Table 3A. Cost, budget, funding sources: public sector

\begin{tabular}{|c|c|c|c|c|c|}
\hline Program & $\begin{array}{l}\text { \# of youth per } \\
\text { year }\end{array}$ & $\begin{array}{l}\text { Annual Budget } \\
\text { GHC }\end{array}$ & $\begin{array}{l}\text { Cost per participants } \\
\text { GHC }\end{array}$ & Sources of funding & Fees \\
\hline YEA & 100,000 & $709,245,854$ & 7,092 & Government & \\
\hline NVTI & 4,000 & $2,892,492$ & 589 & Government & $\checkmark$ \\
\hline GEBSS & 2,000 & $2,550,000$ & 12,750 & Jospong Group\& Government & \\
\hline Corporative Council & 1,000 & 100,000 & 100 & Government & $\checkmark$ \\
\hline ICCES & 3,000 & $5,009,238$ & 686 & Government & $\checkmark$ \\
\hline OICG & 350 & 569,133 & 1620 & Breed of World, Germany & $\checkmark$ \\
\hline MDPI & 6 & & & Government & $\checkmark$ \\
\hline Youth in Agric. & 50,000 & $10,000,000$ & 200 & Government & \\
\hline Youth in Cocoa & 42,882 & & & Government & \\
\hline GRATIS Foundation & 2,194 & $15,013,060$ & 60,005 & Government & $\checkmark$ \\
\hline $\begin{array}{l}\text { Rural Enterprise } \\
\text { Program }\end{array}$ & 26,980 & $84,000,150$ & 3,113 & ADB, IFAD \& Government & $\checkmark$ \\
\hline COTVET-NAP & 5,000 & 750,000 & 150 & Government & \\
\hline COTVET-GSDI & 1,500 & $4,403,288$ & 2,935 & GIZ & \\
\hline YLSTI & 1,500 & $1,000,000$ & 800 & Government & $\checkmark$ \\
\hline YES & 107 & & & Government & \\
\hline $\begin{array}{l}\text { Microfinance and Small } \\
\text { Loans Center }\end{array}$ & NA & NA & NA & NA & \\
\hline Fisheries Commission & 100 & 570,183 & 5701 & FAO & \\
\hline $\begin{array}{l}\text { DBC, Mobile } \\
\text { Applications } \\
\text { Development }\end{array}$ & 55 & 183500 & 3336 & $\begin{array}{l}\text { Fees +IGF, Partners: United } \\
\text { Nations Educational, } \\
\text { Scientific, and Cultural } \\
\text { Organization project \& } \\
\text { Ministry of Youth and Sports }\end{array}$ & $\checkmark$ \\
\hline Total & 240,674 & $835,103,398$ & 3,475 & & 9 \\
\hline
\end{tabular}


Table 3B. Cost, budget, funding sources: private sector

\begin{tabular}{|c|c|c|c|c|c|}
\hline Program & \# of youth & Budget GHC & Cost per \# & Sources of funding & Fees \\
\hline LESDEP training programs & 35000 & 84000000 & 2400 & Jospong Group and the Government & \\
\hline YIEDIE & 1600 & 200020 & 125 & $\begin{array}{c}\text { MasterCard Foundation - Youth Forward } \\
\text { initiative }\end{array}$ & $\checkmark$ \\
\hline Blazing Trails & 1500 & 600000 & 400 & Barclays Bank Ghana & \\
\hline GCEEI programs & 1000 & 100000 & 100 & $\begin{array}{l}\text { Equity Investment \& Returns, Fees, } \\
\text { Sponsorship }\end{array}$ & $\checkmark$ \\
\hline Enterprise and Leadership development & 610 & & 0 & Not disclosed & \\
\hline PII, Ahafo Emerging Talent & 335 & 60000 & 0 & $\begin{array}{c}\text { 60\%- Program Fees } 40-\text { Grants and } \\
\text { Donations }\end{array}$ & $\checkmark$ \\
\hline $\begin{array}{l}\text { ENGINE, Agripreneurship, } \\
\text { Apprenticeship }\end{array}$ & 215 & 6000000 & 27907 & DFID, Barclays, Internal funding & \\
\hline Teacher Professional Development & 200 & 420000 & 2100 & $\begin{array}{l}\text { Plan Ghana, Ministry of Education, Village- } \\
\text { By-Village }\end{array}$ & \\
\hline $\begin{array}{l}\text { Certificate/ Diploma/ Degree in Fashion } \\
\text { Design }\end{array}$ & 171 & 660000 & 3860 & Fees paid, internal funding & $\checkmark$ \\
\hline $\begin{array}{l}\text { Tech Girls \& SGS Vocational Training } \\
\text { Initiative }\end{array}$ & 140 & 80000 & 571 & $\begin{array}{l}\text { Empower Foundation, Internally Generated } \\
\text { Funds }\end{array}$ & \\
\hline $\begin{array}{l}\text { AEA SDC (skills development and } \\
\text { training) }\end{array}$ & 100 & 35,000 & 350 & $\begin{array}{l}\text { IGF, Training contracts for public } \\
\text { institutions \& NGOs }\end{array}$ & $\checkmark$ \\
\hline Enablis Business LaunchPad & 75 & 1200000 & 16000 & UT Bank, Accra Brewery Limited, and so on & \\
\hline Youth Farm \& Market Program & 60 & & 0 & Corporate, Internally Generated Funds & $\checkmark$ \\
\hline Venture Support & 54 & 640000 & 11852 & BBG Grant, sponsorships & $\checkmark$ \\
\hline Student Entrepreneurs Network & 50 & 45000 & 900 & $\begin{array}{c}\text { IGF, Sponsorship - IConceptsPR \& Trade } \\
\text { Hub Ghana }\end{array}$ & \\
\hline Entrepreneur-in-Training Program & 30 & 4000000 & 133333 & Meltwater Group & \\
\hline Reach for Change Program & 24 & 600,000 & 25000 & Corporates and foundations & \\
\hline ServLed Accelerator Program & 20 & & 0 & Self-funded by founders & \\
\hline Cake craft training & 20 & 240000 & 12000 & Shareholders, Directors & $\checkmark$ \\
\hline $\begin{array}{l}\text { DSTC training programs in Solar } \\
\text { technology }\end{array}$ & 15 & & 0 & $\begin{array}{l}\text { GIZ, Australian High Commission, Private } \\
\text { clients }\end{array}$ & $\checkmark$ \\
\hline Incubator Program & 8 & 4000000 & 500000 & Meltwater Group, Interswitch, Vodafone & \\
\hline Student Entrepreneurship & N/A & 300000 & N/A & Donor and partner organizations & \\
\hline Total & 41,227 & $103,180,020$ & 35,090 & & 9 \\
\hline
\end{tabular}


Table 4A. Start year and duration, public sector

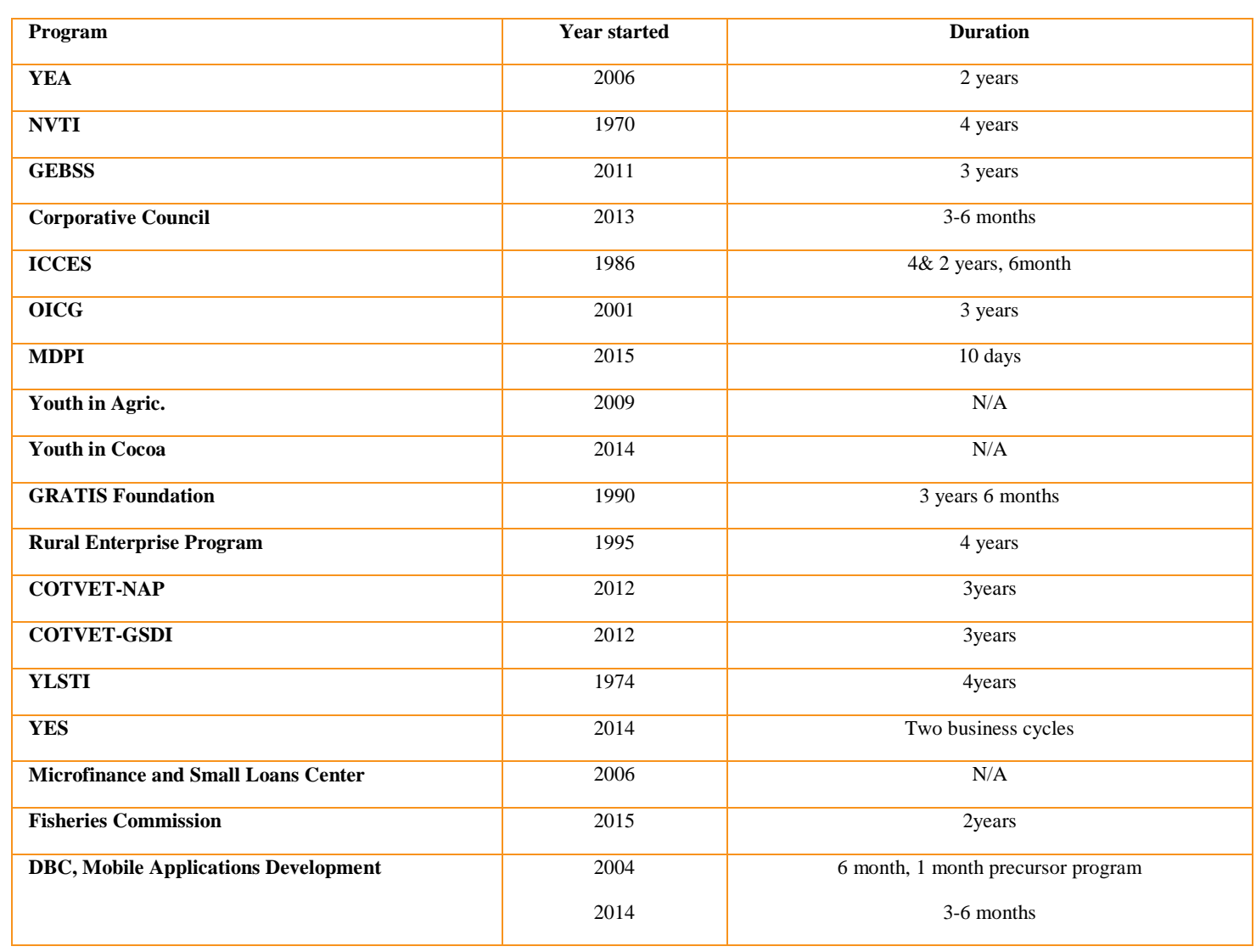


Table 4B. Start year, duration and location, private sector

\begin{tabular}{|c|c|c|c|}
\hline Program & Year started & Duration & Locations \\
\hline LESDEP training programs & 2010 & 3 month - 6 months & All over Ghana \\
\hline YIEDIE & 2015 & $\begin{array}{l}8 \text { weeks- weekends only, } 16 \text { training } \\
\text { sessions. } 5 \text { weeks condensed for year } \\
1 \text { project roll-out only (March 2015- } \\
2016 \text { ). }\end{array}$ & Accra, Takoradi (run simultaneously) \\
\hline Blazing Trails & 2012 & Actual training is for 3 days & $\begin{array}{l}\text { Greater Accra, Western, Volta, Ashanti, Upper } \\
\text { West, Brong Ahafo and Northern }\end{array}$ \\
\hline GCEEI programs & 2011 & 1 day to 1 week programs & $\begin{array}{l}\text { Almost nationwide, implemented via tertiary } \\
\text { campuses }\end{array}$ \\
\hline Enterprise and Leadership Development & $\begin{array}{l}\text { IBP: } 2011-15 \\
\text { Financial literacy } \\
\text { training: } 2011-15\end{array}$ & $\begin{array}{l}\text { IBP: } 5 \text { years } \\
\text { Financial Literacy Training: } 5 \text { years }\end{array}$ & $\begin{array}{l}\text { CAMFED operational regions are Upper West, } \\
\text { Upper East, Northern and Central regions. }\end{array}$ \\
\hline PII, Ahafo Emerging Talent Program & 2014 & $\begin{array}{l}2-3 \text { months } \\
1 \text { month }\end{array}$ & $\begin{array}{l}\text { Brong Ahafo for the Ahafo Emerging Talent } \\
\text { Program; nationwide for PII }\end{array}$ \\
\hline ENGINE, Agripreneurship, Apprenticeship & $\begin{array}{l}\text { ENGINE - Dec 2013, } \\
\text { AGRI - Jan 2015, } \\
\text { APPRE - April } 2015\end{array}$ & $\begin{array}{c}\text { ENGINE }-6 \text { months, AGRI }-1 \text { year, } \\
\text { APPRE }-1 \text { year. }\end{array}$ & $\begin{array}{c}\text { Nationwide participation. Program centers are in } \\
\text { Accra + Kumasi + }\end{array}$ \\
\hline Teacher Professional Development & 2013 & $\begin{array}{l}\text { 1week training with } 12 \text { weeks } \\
\text { monitoring and coaching at } 5 \\
\text { locations }\end{array}$ & $\begin{array}{c}\text { Wa, Atimpoku, Adawso/Koforidua, Afram Plains, } \\
\text { Cape Coast }\end{array}$ \\
\hline $\begin{array}{l}\text { Certificate/ Diploma/ Degree in Fashion } \\
\text { Design }\end{array}$ & $\begin{array}{l}1995 \\
2013 \\
2013\end{array}$ & $\begin{array}{c}1 \text { year }+6 \text { months non-paid internship } \\
2 \text { years } \\
4 \text { years }\end{array}$ & School in Accra \\
\hline $\begin{array}{l}\text { Tech Girls \& SGS Vocational Training } \\
\text { Initiative }\end{array}$ & $\begin{array}{l}2013 \\
2015\end{array}$ & 1 year each & Tamale, Tolon, Sagnarigu, Savelugu \\
\hline $\begin{array}{l}\text { AEA SDC (skills development and } \\
\text { training) }\end{array}$ & 2010 & 8 weeks, Saturday only & $\begin{array}{c}4 \text { training centers: Christ the King church Hall, } \\
\text { Phronesis Hub (Weija-Kasoa), AEA head office, } \\
\text { Legon Campus }\end{array}$ \\
\hline Enablis Business LaunchPad & 2009 (stopped in 2015) & 9 months & Accra, but companies are from all over Ghana \\
\hline Youth Farm \& Market Program & $2009-2014$ & 5 weeks & \\
\hline Venture Support & 2013 & Year round & Accra \\
\hline Student Entrepreneurs Network & 2012 & 6 months & Greater Accra \\
\hline Entrepreneur-in-Training Program & 2008 & 2 years, now 1 year & Accra \\
\hline Reach for Change Program & 2011 & $3-5$ years in the program & $\begin{array}{l}\text { Based in Accra but with social entrepreneurs across } \\
\text { the country }\end{array}$ \\
\hline ServLed Accelerator Program & 2013 & 6 months & Accra \\
\hline Cake craft training & 2016 & $6-12$ months & Accra \\
\hline $\begin{array}{l}\text { DSTC training programs in Solar } \\
\text { technology }\end{array}$ & 2005 & $\begin{array}{c}5 \text { days to } 10 \text { days. Training programs } \\
\text { run at any given period with registered } \\
\text { class of } 15\end{array}$ & Accra, Nkoranza, Bolgatanga, Kumasi and Tamale \\
\hline Incubator Program & 2010 & $\begin{array}{l}\text { Progress measured yearly to review } \\
\text { stay, some move out because of } \\
\text { growth, others go do something else }\end{array}$ & Accra \\
\hline Student Entrepreneurship & 2000 & Year round & 23 tertiary institutions across Ghana \\
\hline
\end{tabular}


Table 5A. Sectors, service providers: public sector

\begin{tabular}{|c|c|c|}
\hline Program & Sectors & Service providers \\
\hline YEA & $\begin{array}{l}\text { Health, education, security services, waste } \\
\text { \&sanitation, agriculture, and so on }\end{array}$ & Public \& private institutions, master craft persons, \\
\hline NVTI & $\begin{array}{l}\text { Constructional artisans, electronics, } \\
\text { automobile, dressmaking, catering }\end{array}$ & Government officials, master craft persons \\
\hline GEBSS & All sectors & Private sectors operatives, entrepreneurs \\
\hline Corporative Council & $\begin{array}{l}\text { Construction, artisans, hairdressing \& } \\
\text { beauticians, catering, small-scale farmers }\end{array}$ & Public \& private Institutions, cooperatives members \\
\hline ICCES & $\begin{array}{l}\text { Construction, artisans, catering, auto } \\
\text { mechanics, hairdressing, electronics, } \\
\text { computer skills }\end{array}$ & Government officials, master craft persons, private sector operatives \\
\hline OICG & $\begin{array}{c}\text { Construction, artisans, dressmaking, } \\
\text { hairdressing, floral \& internal decoration, } \\
\text { and so on }\end{array}$ & Master craft persons, private sector operatives, \\
\hline MDPI & Management \& productivity & Government officials \\
\hline Youth in Agric. & Agricultural value chain & Farm input dealers, agricultural machinery, government officials \\
\hline Youth in Cocoa & Agricultural value chain & Farm input dealers, agricultural machinery, government officials \\
\hline GRATIS Foundation & $\begin{array}{l}\text { Engineering, industrial machinery, } \\
\text { welding, textile production }\end{array}$ & Master craft persons, private sector operatives \\
\hline Rural Enterprise Program & $\begin{array}{l}\text { Agricultural value chain, soap making, } \\
\text { domestic products }\end{array}$ & Private and public sector operatives \\
\hline COTVET-NAP & $\begin{array}{l}\text { Constructional artisans, dressmaking, } \\
\text { hairdressing }\end{array}$ & Mastercraft persons, government officials \\
\hline COTVET-GSDI & $\begin{array}{c}\text { Catering, automobile repairs, consumer } \\
\text { electronics, hair \& beauty, tailoring \& } \\
\text { dressmaking }\end{array}$ & Trades associations, master craft persons \\
\hline YLSTI & $\begin{array}{c}\text { Agriculture, dressmaking, catering, } \\
\text { electrical installation, masonry, carpentry } \\
\text { \& joinery and metal work, computer skills }\end{array}$ & Government officials \\
\hline YES & $\begin{array}{l}\text { Agricultural value chain, health, clothing } \\
\text { designing, fashion \& beauty }\end{array}$ & $\begin{array}{l}\text { Private sector operators, government institutions, entrepreneurial and management } \\
\text { institutions }\end{array}$ \\
\hline $\begin{array}{l}\text { Microfinance and Small } \\
\text { Loans Center }\end{array}$ & Financial, credit \& loans & NA \\
\hline Fisheries Commission & Aquaculture, agricultural value chain & Private sector operators \& government officials \\
\hline $\begin{array}{l}\text { DBC, Mobile Applications } \\
\text { Development }\end{array}$ & ICT & None \\
\hline
\end{tabular}


Table 5B. Sectors, service providers: private sector

\begin{tabular}{|c|c|c|}
\hline Program & Sectors & Service providers \\
\hline LESDEP training programs & Beauty care, IT hardware, etc. & $\begin{array}{c}\text { Trade associations, master craft people. NBSSI for Business } \\
\text { Advisory. Local food vendors. }\end{array}$ \\
\hline YIEDIE & Construction & Kingdom Books for stationery. \\
\hline Blazing Trails & Several & $\begin{array}{l}\text { Event management companies for career fairs, caterers as well and } \\
\text { vendors for printing manuals and other promotional materials for } \\
\text { the program }\end{array}$ \\
\hline GCEEI programs & Several & $\begin{array}{l}\text { Management Consultants and established entrepreneurs, } \\
\text { Technology partners and Brand strategists }\end{array}$ \\
\hline Enterprise and Leadership development & Several & None \\
\hline PII, Ahafo Emerging Talent & Several & Consultants \& resource persons \\
\hline ENGINE, Agripreneurship, Apprenticeship & Entrepreneurship, agribusiness & PWC, independent consultants \\
\hline Teacher Professional Development & Education & $\begin{array}{l}\text { Stationery Shops (Printing, Photocopying, Supply of training } \\
\text { stationery) }\end{array}$ \\
\hline Certificate/ Diploma/ Degree in Fashion Design & Fashion and design & Vodafone for internet, designers for business (seminars), restaurant \\
\hline Tech Girls \& SGS Vocational Training Initiative & ICT, vocations & None \\
\hline AEA SDC (skills development and training) & Several: employees & None \\
\hline Enablis Business LaunchPad & Several: entrepreneurs & None \\
\hline Youth Farm \& Market Program & Agriculture & None \\
\hline Venture Support & Several: social entrepreneurs & $\begin{array}{l}\text { Spectra Wireless (TV Whitespaces) is the internet service provider } \\
\text { (ISP), utilities companies, general \& building contractors, food } \\
\text { services. }\end{array}$ \\
\hline Student Entrepreneurs Network & Several: entrepreneurs & None \\
\hline Entrepreneur-in-Training Program & ICT & Vodafone \\
\hline Reach for Change Program & Several: social entrepreneurs & None \\
\hline ServLed Accelerator Program & Several: entrepreneurs & Legal firms - company secretarial services, Statutory bodies \\
\hline Cake craft training & Hospitality & Guest Instructors \\
\hline DSTC training programs in Solar technology & Solar technology & External trainers. \\
\hline Incubator Program & ICT & Vodafone for internet, Amazon Web services, In-house caterer. \\
\hline Student Entrepreneurship & Several: entrepreneurs & Hotels- provide conference room facilities for Enactus Competitions \\
\hline
\end{tabular}


Table 6A. Targeting, public sector

\begin{tabular}{|c|c|c|c|c|c|}
\hline Program & $\begin{array}{c}\text { Junior high } \\
\text { school }\end{array}$ & $\begin{array}{l}\text { Senior high } \\
\text { school }\end{array}$ & Tertiary & Youth(15-35) & Others \\
\hline YEA & $\sqrt{ }$ & $\checkmark$ & $\sqrt{ }$ & $\sqrt{ }$ & \\
\hline NVTI & $\checkmark$ & $\sqrt{ }$ & & & $\sqrt{ }$ \\
\hline GEBSS & & & $\sqrt{ }$ & & $\sqrt{ }$ \\
\hline Corporative Council & $\sqrt{ }$ & $\sqrt{ }$ & & & $\sqrt{ }$ \\
\hline ICCES & $\sqrt{ }$ & $\sqrt{ }$ & & & $\sqrt{ }$ \\
\hline OICG & $\checkmark$ & $\sqrt{ }$ & & & $\sqrt{ }$ \\
\hline MDPI & & & $\sqrt{ }$ & & $\sqrt{ }$ \\
\hline Youth in Agric. & $\sqrt{ }$ & $\sqrt{ }$ & & $\sqrt{ }$ & \\
\hline Youth in Cocoa & $\sqrt{ }$ & $\sqrt{ }$ & & $\sqrt{ }$ & \\
\hline GRATIS Foundation & $\checkmark$ & $\sqrt{ }$ & & & $\sqrt{ }$ \\
\hline Rural Enterprise Program & & & & & $\sqrt{ }$ \\
\hline COTVET-NAP & $\checkmark$ & & & $\checkmark$ & \\
\hline COTVET-GSDI & $\sqrt{ }$ & $\sqrt{ }$ & & & $\sqrt{ }$ \\
\hline YLSTI & & & & $\sqrt{ }$ & \\
\hline YES & & & $\sqrt{ }$ & $\sqrt{ }$ & \\
\hline Microfinance and Small Loans Center & NA & NA & NA & NA & NA \\
\hline Fisheries Commission & $\checkmark$ & $\sqrt{ }$ & & $\sqrt{ }$ & \\
\hline DBC, Mobile Applications Development & & $\sqrt{ }$ & & $\checkmark$ & \\
\hline Total & 11 & 11 & 4 & 8 & 9 \\
\hline
\end{tabular}


Table 6B. Targeting, private sector

\begin{tabular}{|c|c|c|c|c|c|}
\hline Program & $\begin{array}{c}\text { Junior high } \\
\text { school }\end{array}$ & $\begin{array}{c}\text { Senior high } \\
\text { school }\end{array}$ & Tertiary & Youth(15-35) & Others \\
\hline LESDEP training programs & $\sqrt{ }$ & $\sqrt{ }$ & $\sqrt{ }$ & & \\
\hline YIEDIE & & $\sqrt{ }$ & & $\sqrt{ }$ & $\sqrt{ }$ \\
\hline Blazing Trails & & & $\sqrt{ }$ & $\sqrt{ }$ & $\sqrt{ }$ \\
\hline GCEEI programs & $\sqrt{ }$ & $\sqrt{ }$ & & $\sqrt{ }$ & $\sqrt{ }$ \\
\hline Enterprise and Leadership development & $\sqrt{ }$ & $\sqrt{ }$ & $\sqrt{ }$ & $\sqrt{ }$ & $\sqrt{ }$ \\
\hline PII, Ahafo Emerging Talent & $\sqrt{ }$ & $\sqrt{ }$ & $\sqrt{ }$ & $\sqrt{ }$ & $\sqrt{ }$ \\
\hline ENGINE, Agripreneurship, Apprenticeship & & & $\sqrt{ }$ & & $\sqrt{ }$ \\
\hline Teacher Professional Development & $\sqrt{ }$ & $\sqrt{ }$ & $\sqrt{ }$ & & $\sqrt{ }$ \\
\hline Certificate/ Diploma/ Degree in Fashion Design & $\sqrt{ }$ & $\sqrt{ }$ & & $\sqrt{ }$ & \\
\hline Tech Girls \& SGS Vocational Training Initiative & $\sqrt{ }$ & $\sqrt{ }$ & & $\sqrt{ }$ & \\
\hline AEA SDC (skills development and training) & & $\sqrt{ }$ & $\checkmark$ & $\sqrt{ }$ & $\sqrt{ }$ \\
\hline Enablis Business LaunchPad & & & $\sqrt{ }$ & $\sqrt{ }$ & \\
\hline Youth Farm \& Market Program & $\sqrt{ }$ & $\sqrt{ }$ & & $\sqrt{ }$ & $\sqrt{ }$ \\
\hline Venture Support & & & $\checkmark$ & $\sqrt{ }$ & \\
\hline Student Entrepreneurs Network & & & $\sqrt{ }$ & $\sqrt{ }$ & \\
\hline Entrepreneur-in-Training Program & & & $\sqrt{ }$ & $\sqrt{ }$ & $\sqrt{ }$ \\
\hline Reach for Change Program & & & $\sqrt{ }$ & $\sqrt{ }$ & $\sqrt{ }$ \\
\hline ServLed Accelerator Program & & & $\sqrt{ }$ & $\sqrt{ }$ & \\
\hline Cake craft training & & $\sqrt{ }$ & & $\sqrt{ }$ & \\
\hline DSTC training programs in Solar technology & & $\sqrt{ }$ & $\sqrt{ }$ & & $\sqrt{ }$ \\
\hline Incubator Program & & & $\sqrt{ }$ & $\sqrt{ }$ & \\
\hline Student Entrepreneurship & & & $\sqrt{ }$ & $\sqrt{ }$ & \\
\hline Total & 8 & 12 & 16 & 18 & 12 \\
\hline
\end{tabular}


Table 7A. Other Services, public sector

\begin{tabular}{|c|c|c|c|c|c|}
\hline Program & MDAs & Tracer Study & $\mathbf{M} \& \mathbf{E}$ & Exit Strategy & $\begin{array}{l}\text { After care } \\
\text { Support }\end{array}$ \\
\hline YEA & MELR & & $\checkmark$ & $\checkmark$ & \\
\hline NVTI & MELR & $\checkmark$ & $\checkmark$ & & \\
\hline GEBSS & MELR & & $\checkmark$ & & \\
\hline Corporative Council & MELR & & & & \\
\hline ICCES & MELR & $\checkmark$ & $\checkmark$ & & \\
\hline OICG & MELR & $\checkmark$ & $\checkmark$ & & \\
\hline MDPI & MELR & & $\checkmark$ & & \\
\hline Youth in Agric. & MOFA & & $\checkmark$ & & $\checkmark$ \\
\hline Youth in Cocoa & Ministry of Finance & & $\checkmark$ & & $\checkmark$ \\
\hline GRATIS Foundation & Ministry of Trade and Industry & $\checkmark$ & $\checkmark$ & & \\
\hline Rural Enterprise Program & Ministry of Trade and Industry & & $\checkmark$ & & \\
\hline COTVET-NAP & Ministry of Education & & & & \\
\hline COTVET-GSDI & Ministry of Education & $\checkmark$ & $\checkmark$ & & \\
\hline YLSTI & Ministry of Youth and Sports & & $\checkmark$ & & \\
\hline YES & Office of President & & $\checkmark$ & & $\checkmark$ \\
\hline $\begin{array}{l}\text { Microfinance and Small } \\
\text { Loans Center }\end{array}$ & Office of President & & & & \\
\hline Fisheries Commission & $\begin{array}{l}\text { Ministry of Fisheries and } \\
\text { Aquaculture Development }\end{array}$ & & & & \\
\hline $\begin{array}{l}\text { DBC, Mobile Applications } \\
\text { Development }\end{array}$ & & $\sqrt{ }$ & $\sqrt{ }$ & $\sqrt{ }$ & \\
\hline Total & & 6 & 14 & 2 & 3 \\
\hline
\end{tabular}


Table 7B. Other Services, private sector

\begin{tabular}{|c|c|c|c|c|}
\hline Program & Tracer Study & $\mathbf{M \& E}$ & Exit Strategies & After-care \\
\hline LESDEP training programs & $\sqrt{ }$ & $\sqrt{ }$ & $\sqrt{ }$ & $\sqrt{ }$ \\
\hline YIEDIE & $\sqrt{ }$ & $\sqrt{ }$ & $\sqrt{ }$ & $\sqrt{ }$ \\
\hline Blazing Trails & & $\sqrt{ }$ & $\sqrt{ }$ & $\sqrt{ }$ \\
\hline GCEEI programs & & $\sqrt{ }$ & $\sqrt{ }$ & $\sqrt{ }$ \\
\hline Enterprise and Leadership development & & $\sqrt{ }$ & $\sqrt{ }$ & $\sqrt{ }$ \\
\hline PII, Ahafo Emerging Talent & & & $\sqrt{ }$ & \\
\hline ENGINE, Agripreneurship, Apprenticeship & & $\checkmark$ & $\sqrt{ }$ & $\sqrt{ }$ \\
\hline Teacher Professional Development & & $\sqrt{ }$ & $\sqrt{ }$ & $\sqrt{ }$ \\
\hline Certificate/ Diploma/ Degree in Fashion Design & $\sqrt{ }$ & $\sqrt{ }$ & $\sqrt{ }$ & $\sqrt{ }$ \\
\hline Tech Girls \& SGS Vocational Training Initiative & & $\sqrt{ }$ & & $\sqrt{ }$ \\
\hline AEA SDC (skills development and training) & $\sqrt{ }$ & & $\sqrt{ }$ & \\
\hline Enablis Business LaunchPad & & $\sqrt{ }$ & $\sqrt{ }$ & $\sqrt{ }$ \\
\hline Youth Farm \& Market Program & & & $\sqrt{ }$ & $\sqrt{ }$ \\
\hline Venture Support & & $\sqrt{ }$ & $\sqrt{ }$ & $\sqrt{ }$ \\
\hline Student Entrepreneurs Network & & $\sqrt{ }$ & & $\sqrt{ }$ \\
\hline Entrepreneur-in-Training Program & & $\sqrt{ }$ & $\sqrt{ }$ & $\sqrt{ }$ \\
\hline Reach for Change Program & & $\sqrt{ }$ & $\sqrt{ }$ & \\
\hline ServLed Accelerator Program & & $\checkmark$ & $\sqrt{ }$ & $\sqrt{ }$ \\
\hline Cake craft training & & $\sqrt{ }$ & $\sqrt{ }$ & \\
\hline DSTC training programs in Solar technology & & $\sqrt{ }$ & $\sqrt{ }$ & $\sqrt{ }$ \\
\hline Incubator Program & & $\sqrt{ }$ & $\sqrt{ }$ & $\sqrt{ }$ \\
\hline Student Entrepreneurship & & $\sqrt{ }$ & & \\
\hline Total & 4 & 19 & 19 & 17 \\
\hline
\end{tabular}




\section{ANNEX: YOUTH EMPLOYMENT PROGRAM DESCRIPTIONS}

\section{Public Sector}

1. YEA: The YEA was established under the Youth Employment Act 2015 (Act 887) to empower young people to contribute meaningfully to the sustainable socioeconomic and development of the nation. Its objective is to provide skills training and apprenticeship modules to support youth ages 15-35 years during the transition from unemployment to employment. YEA targets all categories of youth and most of the key sectors in Ghana (health, education, agricultural, security). It is being implemented through modules that include youth in afforestation, health, education, security services, and so on.

2. NVTI: NVTI provides demand-driven employable skills and enhances the income-generating capacities of basic and secondary school leavers and others through competency-based apprenticeship, master craftsmanship, testing and certification, and career development. Act 351 of 1970 established the institute, which is also supported by Apprentice Regulations LI 1151 of 1978, Clerical and Secretarial Training Regulations LI 981 of 1974, and Trade Testing LI 715 of 1971. NVTI has 34 training centers across all 10 regions of Ghana. NVTI targets junior and senior secondary school graduates and focuses on the construction and the consumer electronics sectors.

3. GEBSS: GEBSS focuses on supplying training and support services to help unemployed tertiary graduates establish their own businesses in all sectors. It assists beneficiaries to develop bankable business plans in all sectors and supports them in gaining access to funding, including the possible establishment of a graduate credit insurance guarantee scheme through a public-private partnership.

4. Jobs Creation and Development-Ghana Cooperative Council: The program includes four projects covering construction artisans, the reorganization of agricultural cooperatives, skills development, and the training of cooperative hairdressers and beauticians and cooperative entrepreneurial development. The program does not have training centers. They rent out district locations to train beneficiaries. The program does not primarily target youth.

5. ICCES: ICCES trains youth in demand-driven employable skills for self- or paid employment in their chosen trades through micro- and small enterprise development to combat youth unemployment and thereby dampen rural-urban drift. ICCES has 60 training centers in remote communities in the 10 regions of Ghana. Unlike NVTI, the training programs target illiterate, semiliterate, and literate youth in rural areas. ICCES focuses on the construction, automobiles, electronics, catering, and beauty sectors within local community development.

6. The LEFY Program of OICG: LEFY was established in 1971 to provide skills training to illiterate and semiliterate youth in Accra, Kumasi, and Takoradi through an improved apprenticeship program. The project represents an improvement on traditional apprenticeship that entails hands-on training among unskilled youth who are attached to master craftpersons in various trades. LEFY targets junior and senior high school leavers, placing them into apprenticeships with master craftpersons on the basis of agreements. The construction, food and nutrition, and beauty sectors are the main focus. 
7. Competency Training for Fresh and Unemployed Graduates-MDPI: This pilot program aims to equip tertiary graduates with entrepreneurial skills for self-employment in all sectors. However, the fees are too high for most unemployed graduates.

8. Youth in Agriculture Program: This is an agro-incubator with the objective of motivating youth to accept and appreciate farming and food production as commercial ventures. The program provides young farmers with tractor services and inputs at subsidized prices on interest-free credit to produce food crops, meat, and fish using modern methods thus contributing to national food security and youth employment. The program focuses on rural youth in the agricultural sector.

9. Youth in Cocoa: The program targets rural youth in the agricultural sector. It is aimed at producing cocoa as a cash crop for export. The beneficiaries are trained by cocoa extension agents and supported through the provision of cocoa seedlings, growth-enhancing fertilizers, tree seedlings, and agrochemicals.

10. GRATIS Foundation: The foundation aims to equip men, women, youth, and the elderly with requisite technical, vocational, and entrepreneurial skills for self-employment. GRATIS provides technical and engineering training in metal-machining, welding and fabrication, woodworking and pattern making, and foundry work for manufacturing industries, which are sectors generally not covered by the NVTI.

11. Rural Enterprise Program: The program seeks to improve the livelihoods and incomes of rural poor microand small entrepreneurs and increase the number of rural small and medium enterprises that generate profits, growth, and employment opportunities. The program primarily targets the entrepreneurial poor. However, special youth support interventions, such as the Youth in Agri-business Program, are being implemented in collaboration with the Ministry of Food and Agriculture, for which the age range is 18-35 years. The program focuses on agroprocessing in the development of local economies.

12. COTVET-NAP: The program was established within the informal division of COTVET to ensure that junior high school graduates who could not access senior high school education are given employable skills through modern apprenticeship. Beneficiaries work in the construction, automotive, electronics, and beauty sectors.

13. COTVET-GSDI: Funded by the GIZ, in partnership with COTVET, this program aims at modernizing traditional apprenticeships through an innovative approach to competency-based training and by strengthening trade associations and training institutions. GSDI associates apprenticeship with competencybased training standards and a cooperative training model, combining workplace and school-based training. The program targets junior high school, senior high school, and semiliterate youth in the construction, consumer electronics, catering, and beauty sectors

14. YLSTI: This initiative prepares youth to assume the responsibilities of adult life and to contribute to national development. It provides technical, vocational, and leadership skills training for youth in rural areas. The program targets junior and senior secondary graduates and illiterate youth in the construction, agricultural, catering, and beauty industries and aims at the development of local economies. 
15. YES: Dedicated to growing Ghana's economy by tapping into the creativity and innovativeness of young entrepreneurs, the program provides financial, technical, and expert advisory services to young businesspeople. The financial support involves offering interest-free loans to qualified start-ups and existing businesses owned by youth. Presently, YES offers a maximum loan amount of GHC50,000 per beneficiary. The beneficiaries operate businesses in agriculture and agribusiness, manufacturing and cottage industries, and the services sector.

16. Microfinance and Small Loans Center: This microfinance apex body is responsible for implementing the government's microfinance programs targeted at reducing poverty and creating jobs and wealth. It provides loans to beneficiaries in various sectors to support their businesses. It is not focused entirely on youth.

17. Creating agribusiness opportunities for youth through sustainable aquaculture systems and cassava value chains in West Africa, the Fisheries Commission: The commission creates decent agribusiness employment opportunities for youth by exploring and taking advantage of initiatives with great agriculture potential to spur growth and development. The program targets youth in coastal areas in the fisheries subsector of the agricultural industry.

18. AITI-KACE programs: These programs target youth for employment in the ICT sector through two programs:

a. The DBC trains in software engineering, database concepts, and Oracle (proprietary database) and builds development skills. Students are exposed to the enterprise side technology.

b. Mobile Applications Development trains youth on Androids exclusively with the Core Java app for development training.

\section{Private Sector}

1. LESDEP programs: These programs provide skills training and start-up kits. They are not focused entirely on youth. They assist people involved in hairdressing and beauty care and artisans (such as mechanics). LESDEP works with Union Savings \& Loans, which creates accounts so that beneficiaries may access loans. The programs offer business advisory training to program graduates.

2. YIEDIE (YES-GHANA): This program provides youth with soft and technical skills training and entry into the construction sector. The youth become entrepreneurs or are employed under master craftspeople. The goal is to train 23,700 youth over five years.

3. Blazing Trails (British Council-Ghana): This program provides hands-on training focused on key skills development in employability and entrepreneurship among participants in all sectors. It targets graduates, final-year tertiary students, out-of-school youth, and young entrepreneurs.

4. GCEEI programs: These programs focus on identifying, training, and connecting youth to resource providers who will help them start their own businesses, equipping them with the tools to start, scale up, and have an impact. They target youth in all sectors.

5. CAMFED-Ghana Enterprise and Leadership Development programs: These programs target young women in the Northern, Upper West, Upper East, and Central regions through two programs: 
a. The Innovation Bursary Program provides skills training in agroprocessing, batik, tie \& dye, soap making, baking, and so on to young women to set up innovative businesses. It also facilitates start-up KIVA Microfunds grants and loans for the women.

b. The Financial Literacy Training Program increases knowledge on and utilization of financial services and the establishment of more woman-owned businesses in all sectors by sharing knowledge on leadership skills, communication, and so on.

6. Global Alliance for Development Foundation Programs: This targets youth through two programs:

a. PII develops the next generation of social entrepreneurs through mentorship, fellowships, training, and support services, including incubation and start-up funds.

b. Ahafo Emerging Talent searches for talented high-performing students in tertiary institutions for Ahafo companies and foundations.

7. TechnoServe programs: These programs target youth through three programs:

a. ENGINE provides entrepreneurial training for enterprises in all sectors. The enterprises receive support in the form of seed capital, mentoring, and networking aid through market and financial links.

b. Agripreneurship is an accelerator for existing and new agribusiness entrepreneurs.

c. Apprenticeship offers training for university graduates to become more employable and placement in institutions in all sectors.

8. Teacher Professional Development (NOVAN Education \& Training): This program provides training among education personnel who have completed formal training. NOVAN helps those in the teaching field maintain or increase their competence and learn about new and developing areas in education. It is not focused entirely on youth.

9. Joyce Ababio College of Creative Design Certificate, Diploma, and Degree in Fashion Design Programs: This for-profit organization trains students as fashion and creative design professionals; participants must produce 10 garments to graduate in the certificate course. The organization also runs certificate, diploma, and degree programs.

10. Savana Signatures Programs: These programs target youth in the Northern, Upper East, Upper West, and Volta regions through two programs:

a. Tech Girls Program: young girls are trained in basic programming skills for the ICT sector.

b. Vocational Training Initiative: focuses on training school youth on computer hardware, maintenance, and networking for the ICT sector.

11. AEA programs: These target youth through two programs:

a. AEA LaunchPad Executive Certificate in Entrepreneurship and Business Management: conducts entrepreneurship training (includes mentoring).

b. AEA Skills Development and Training Certificate: trains in bead-making, communication design (web and graphic design, video editing), and film production.

12. Business LaunchPad (Enablis Ghana): This program works with innovative and viable business ideas that will be groomed into sustainable ventures to create jobs. The competition provides an opportunity for entrepreneurs to gain invaluable expert training and advice to take their small businesses and ideas to a higher level. Business coaches work with the various companies. It targets youth in all sectors. 
13. Youth Farm \& Market Program (Africa Youth Network): This program organizes seminars, workshops, and training programs on entrepreneurships and agribusiness for youth. It targets youth for employment in the agricultural sector.

14. Venture Support (Impact Hub Accra): This program supports budding entrepreneurs through business model validation and investment preparedness training. It seeks to enhance the social impact of entrepreneurs and assist ventures so these are able to scale across West Africa. There is a strong focus on the base of pyramid markets. The program includes training, hyper-accelerator programs, mentoring, investor feedback through capital advisors, connections to potential funders and partners, and so on.

15. Student Entrepreneurs Network (African Network of Entrepreneurs): The program is designed to empower and transform students to become job creators, to provide relevant resources and support, through mentoring, to establish productive networks for student entrepreneurs, and to kick start the creation of businesses directly within education.

16. Entrepreneur-In-Training Program (Meltwater Foundation): This program trains technology entrepreneurs to run startups through a one-year intensive program. Free tuition is provided for all students from Ghana, Kenya, and Nigeria. The program targets youth who have completed tertiary education. Beneficiaries run technology start-ups in various sectors.

17. Reach for Change Foundation programs: These programs train young entrepreneurs who run enterprises that impact children. These enterprises operate in all sectors, as follows:
a. Tigo Digital Changemakers (partner: Millicom).
b. Game Changers (partner: Viasat 1).
c. IMAGINEGhana (partner: United Nations Children's Fund Ghana).
d. Bayport Teacher Innovation Competition (partner: Bayport Financial Services).

18. Accelerator Program (ServLed Africa Limited): This program helps entrepreneurs through idea validation, scaling up businesses, mentoring, and cash injection. It targets youth exclusively, many of whom have completed tertiary education. These youth-led enterprises are spread across all sectors.

19. Cake craft training (STESI GH): This for-profit organization runs several courses on cake craft. The intensive courses train novices and create professionals for the cake industry in 6-12 months. It focuses on youth, mostly up to secondary education graduates.

20. Solar Training programs (DSTC Solar Training Centre): This for-profit organization offers various courses in the design, installation, and maintenance of stand-alone photovoltaic and grid-connected solar systems. The program consists of classroom theory lectures and hands-on practical workshops and trains beneficiaries for the renewable energy sector. It is not entirely focused on youth.

21. Incubator Program (Meltwater Foundation): The program provides mentorship, funding, and incubation to technology entrepreneurs. It offers a $\$ 50,000$ investment for 20 percent equity and a 10 percent stake, and fully sponsored education via the Meltwater Entrepreneurial School of Technology for a 30 percent stake. It targets youth who have completed tertiary education and want to run technology start-ups. 
22. Student Entrepreneurship Program (Enactus Ghana): This program trains and works with university students to help start enterprises. It targets youth in all sectors. It aims at providing sustainable solutions to ensure that the Sustainable Development Goals are met through entrepreneurial action. The program focuses on ensuring that students and their communities are equipped with the best skills for their long-term advancement. 